The Polish Journal of the Arts and Culture. New Series 9

(1/2019): 135-139 [REPORT]

\title{
The 44th Spalding Symposium on Indian Religions, 12-14 April 2019, Lancaster. A conference report
}

\section{Joanna GruszewsKA}

The Spalding Symposium on Indian Religions is a conference which promotes knowledge about Indian religions practised anywhere in the world and those which are observed in South Asia. It constitutes a platform for the presentation of research based on a wide array of methods, including, textual, historical, ethnographical, sociological and philosophical. The concept for the establishment of the Spalding Symposium on Indian Religions originated in Cambridge in 1975, initiated by Professor Karel Werner. Financially supported by the Spalding Trust, the conference is an annual event. It was held in Oxford for many years, but since 2014 it has been hosted by various British institutions of scholarship. Heretofore the symposia have been held in Cambridge, Oxford, Manchester, Cardiff, Edinburgh and Durham. In recent years the conference has focused on a selected theme. The forty-fourth iteration of the conference presented papers which refer to the subject of gender in South Asian religions. It was organised by the University of Lancaster in the main building of the Storey Institute in Lancaster on 12-14 April 2019.

As each year, the symposium presented a dozen or so papers; apart from papers contributed by regular participants, there were also two lectures presented by guest professors and a panel of $\mathrm{PhD}$ students. In the recent years it has been a tradition that one of the main keynote speakers is an employee of the university that hosts the symposium in a given year. The 2019 incarnation of the conference was inaugurated by a lecture by Professor Chakravarthi Ram-Prasad (a Fellow of the British Academy and Distinguished Professor of Comparative Religion and Philosophy at Lancaster University) entitled Anger and Gender: A Sideways Look Through Rasa Theory at Draupadī and 
Bhima. In his lecture, Ram-Prasad presented an analysis of the dynamics of female and male anger on the basis of two episodes of the Mahābhärata - the speaker presented the manner in which Bhìma and Draupadī differ in their expression of anger and the manner in which the same content is communicated by female and male characters.

In her presentation entitled Menstruation, Transgression and the Othering of the Female Body in the Sanskrit Tradition, Doctor Lidia Wojtczak from the London-based School of Oriental and African Studies (SOAS) drew attention to the socio-cultural conditions of the impurity of menstruating women in the ritual and social dimension, and she presented, on the basis of Sanskrit literature, the roots of the menstruation-related taboo which is widespread in South Asia today.

In a paper entitled Women and early hathayoga James Mallinson, a Professor of the School of Oriental and African Studies, analysed what the texts of the hathayoga tradition say about the practice of women. This research topic is particularly interesting because even though today, in the global dimension, yoga is practiced mainly by women; source texts of the hathayoga tradition say little about practicing women, and in some cases they instruct yogin-men to avoid their company completely. Mallinson familiarised the audience with the few fragments of Sanskrit texts which discuss women who practise hathayoga, as well as the images of yogin-women in art, with particular reference to the painting of the Moghul period and temple iconography.

In a paper entitled Gāndhārì's Mapping [of] the Battlefield through the "Divine Eye:" Toward the Hermeneutic of Reversing the Masculine Gaze and Resisting Violence Veena Howard (California State University) analysed the vision of Queen Gandhari (Gāndhārī') from the Book of women (strī parva) the eleventh book of the Mahabharata, in which Gandhari, who gazes with a divine eye upon the battlefield, laments the dead and the despair of women, presenting a woman's outlook on war, one that is inconsistent with the male ethics of war and valour presented in the Bhagavadgita (Bhagavadgit $\bar{a}$ ). According to Veena Howard, Anugita (Anugìtā) - a recapitulation of the Bhagawadgita from the fourteenth book of the Mahabharata - may be interpreted as a text which counterbalances the male ethics of war and corresponds with Gandhari's lament.

The theme of the epic poems was continued by Emily Hudson in a presentation entitled Hard-Hearted Kings and Their Abandoned, Long-Suffering Queens: Gendered Aesthetics in the Vālmìki Rāmāyaṇa which focused on the 
theme of the rejected wife in the epic of the Rāmāyana. She presented the story of Sìtā in the perspective of the poetics of Ānandavardhana, suggesting that it should be interpretedas a text constructed in such a manner as to elicit compassion for the female protagonist on the part of the reader.

The Ramayana was also addressed by the first of the papers featured in the panel of PhD students - Gender Balancing in Vālmìki's Rāmāyaña and the Adbhuta Rāmāyaṇa, Katie Work from the University of Lancaster, in which the speaker analysed the Adbhuta Rāmāyaṇa, a version in which Sītā constitutes the protagonist of the story, focusing on the models of femininity and masculinity that are presented.

In a paper entitled Dialogues between women and Brahmins in the Therigāth $\bar{a}$ Joanna Gruszewska from the Jagiellonian University presented an analysis of three works from the collection known as Therīga tha $\bar{a}$, in which Buddhist female monks debate with Brahmins and bring about their conversion. The main theme of the paper was constituted by reflection on the interrelationships between the sex of the speaker and the rhetorical strategies which are used in the dialogues in question.

In a paper entitled Gender constructions in the theological dimension of the Sufi premākhyāns: a look at Usmān's Citrāvalì Annalisa Bocchetti from the "Orientale" University in Naples discussed the ways in which women and

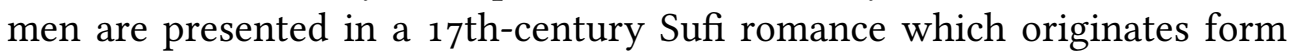
northern India. The speaker analysed the interrelationships between asceticism and eroticism in the work, indicating their relations with the social constructs of that time, and presenting on this basis a reflection on the relations between Islam and Hinduism in the India of the Mogul period.

The presentation of Monica Hirmer, a PhD student at the School of Oriental and African Studies, Becoming the Goddess: Reimagining Gender and Motherhood in a Contemporary South Indian Srīvidya Tradition was one of a series of lectures which engage the problem of gender in Tantric currents. Hirmer presented conclusions gleaned during field research in the Śrividyā tradition. She reflected on the representations of femininity and maternity, exploring cosmological texts of the tradition and providing a creative attitude toward the criticism of a Eurocentric approach and feminism.

In the plane of field research, the tantric tradition was also the subject of a paper by E. Sundari Johansen Hurwitt (California Institute of Integral Studies), which was entitled The Goddess and Her Shadow: Gender, Menstruation, Purity, and Power in Kumārī Worship in Assam. The PhD student familiarised 
the audience with conclusions gleaned on the basis of research conducted in the Kāmākhyā temple and research in source texts. Her paper focused on the kumar $\bar{\imath}$ ritual (kumāri $p \bar{u} j \bar{a})$, and the ritual ambivalence and liminality of menstruation.

The final part of the sessions run by $\mathrm{PhD}$ students included a paper by Ruth Westoby (School of Oriental and African Studies) entitled Rajas: female principle of the yogic body. The presentation continued the theme of the construction of cultural gender in the dimension of hathayoga. The speaker made reference to the yogic models of corporality in the dimension of hathayoga.

In a paper entitled Worldly Affairs: Femininity and Divinity in a Premodern Tamil Literary Work, Ofer Peres from the Hebrew University of Jerusalem presented the constructions of cultural gender in the Tamil work entitled Purūrava-caritai, an adaptation of the story of the Urvaśī and Purūravas, which was featured as early as in the Vedic period. The speaker demonstrated that the text consciously uses the model of the figure of Sita from the $R \bar{a} m \bar{a}-$ yana.

In a paper entitled Patrilocality in the Harivamśa, Simon Brodbeck from the University of Cardiff analysed the theme of patrilocality in the Hariwanśa (Harivamśa). By exploring the problems of the marriage of Krishna and that of his sons, the author presented the dynamics between patrilocality and the matrilocality in the text.

In a paper entitled The motif of tree goddess and women's empowerment in the ancient and contemporary India, Marzenna Jakubczak from the Pedagogical University in Kraków traced the evolution of the iconographical theme of the woman and the tree in Indian mythology and art, making reference to its use in works of modern art and its utilisation by social and ecological organisations.

In a presentation entitled The origin of the yoni pitha in Tantric mythology: Gender dialectic and sakti's supremacy at Kāmākhyā, Paolo Rosati from the Rome-based Sapienza University, by making reference to source texts which discuss the origin of the Kamakhya temple, as well as conclusions gleaned from the author's own ethnographical research, advanced a thesis about the deprivation of the sexual nature of a sacred place which, according to myth, is thought to have originated from the vulva of the goddess.

The conference was concluded by keynote lecture Professor Sondra Hausner from the University of Oxford entitled Gender, Ritual, and Hierarchy: 
Ascetic Inversions at the Great Indian Kumbh Mela. Professor Hausner familiarised the audience with the problems of gender in terms of asceticism on the basis of her field research conducted during Kumbh Mela - a regularly celebrated holiday attended by numerous pilgrims.

The Spalding Symposium on Indian Religions constitutes an extremely interesting opportunity to present research in Indian religious and to familiarise the audience with the most recent research trends in this field. One should praise the organisers for their effort to develop an interdisciplinary conference and to combine presentations which analyse common problems by means of various methods, which is discernible owing to the examples furnished, among other things, by the theme of menstruation - a topic which recurred in a number of presentations and which was explored from a number of perspectives, such a textual analysis and ethnographical research. The premise of the Spalding Symposium on Indian Religions does not stipulate the organisation of a number of parallel panels - a staple of so many conferences. This enables each participant to hear all presentations and to engage in discussions. As far as my own perspective - that of a participant of the $\mathrm{PhD}$ panel - is concerned, the opportunity to present and to discuss the results of my research with experienced scholars was of particular value.

The future, forty-fifth incarnation of the Spalding Symposium on Indian Religions will be held in Edinburgh in 24-26 April 2020 whose theme will be "Comparison(s)".

\section{Note about the author}

Joanna GruszewsKA has recently obtained $\mathrm{PhD}$ in literary sciences from Jagiellonian University. She holds MA in Indology and in Religious studies. Her research interests include literature of early Buddhism in Pali and Sanskrit, Buddhist monasticism and social aspects of Buddhism.

E-MAIL: joannagruszewska@o2.pl 